\title{
Instructing Educators in the Use of Assistive Technology Listening Devices in the Classroom
}

\author{
Abdullah K. Alodail ${ }^{1}$ \\ ${ }^{1}$ School of Education, Al-Baha University, Al-Baha, Kingdom of Saudi Arabia \\ Correspondence: Abdullah K. Alodail, School of Education, Al-Baha University, Al-Baha, Kingdom of Saudi \\ Arabia. E-mail: aa137206@ohio.edu
}

Received: February 14, 2014 Accepted: March 24, 2014 Online Published: April 28, 2014

doi:10.5539/ies.v7n5p55

URL: http://dx.doi.org/10.5539/ies.v7n5p55

\begin{abstract}
The present study will present Kemp's design in the classroom setting for students with hearing impairments. Based on his model, the researcher will design various instructional methods of how to teach students with hearing aids in the school, focusing on the instruction of English to America K-12 students. The study will also include a list of assistive technology devices that can be used by students with hearing problems. Assistive technology listening derives have already played an important role in students' learning environments. Improvements and developments have been made in using hearing aids and FM systems in the classroom, particularly for those with hearing impairments. Taking the improvement into account researcher argues that assistive technology listening devices play an essential role between teachers and students in learning environments by giving both sides opportunities access information that otherwise would be unavailable.
\end{abstract}

Keywords: assistive technology, instruction, listening devices, classroom

\section{Introduction}

Kemp's design is crucial to instruction in the classroom setting, and many researchers see that Kemp's design can be related to the previous and current studies of instructional design. Kemp's model built on ADDIE model and four components instructional and invented by adding nine steps as shown in Figure 1. Morrison, Ross, and Kemp (2007) discussed nine-level models of the instructional design process: instruction problems, learner characteristics, task analysis, instructional objectives, content sequencing, instructional strategies, designing the message, development of instruction, and evolution instruments. An instructional design model generally plays an indispensable role in providing support and a sequence of instruction that organizes the instructional tasks within the school in order to achieve specific objectives. Kemp's design model is particularly well-adapted to working with students who have hearing impairments. 


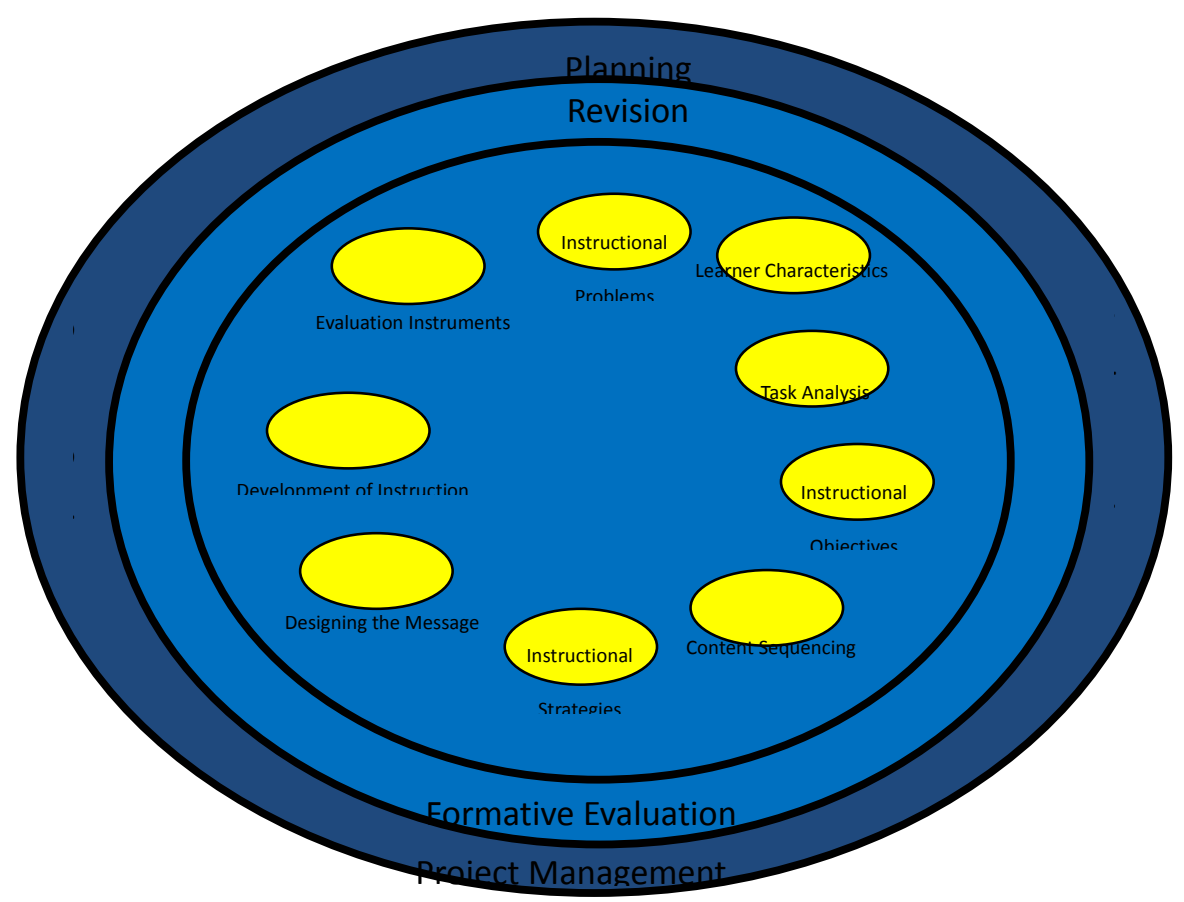

Figure 1. Instructional design process adapted from designing effective instruction Morrison, Ross, and Kemp (2007)

\section{A. Instructional Problems (Background)}

\section{1) Who?}

This project will examine students with disabilities, in particular, students with hearing impairments at Trimble Middle School. In the class that has been observed, there are students with hearing impairments-both female and male and they are Americans. The researcher will provide information regarding instruction of grade- five students with a hearing amplification device. The student receiving altered instruction has a need for voice amplification to compensate for mild hearing impairment and distractive noise reduction. The FM amplification and hearing aid devices are capable of amplifying a teacher's voice with clarity and reducing extraneous noise.

\section{2) What?}

While studying at Ohio University, I have found students with hearing impairments who take classes are motivated to learn and who get familiar with the information. The researcher wants to understand how to use assistive technology devices in teaching and learning, especially hearing devices. students:

Professional staff goals set by Trimble Middle School staff provide instruction for hearing impaired - Student should receive the same curriculum as his/ her peers, primarily the mastering of standards set by the state of Ohio in all subject areas.

- Develop the appropriate arrangements so student can perform maximally in a regular education program with his/ her grade level peers.

- The staff will assess the student, give feedback, and watch for any patterns in student's progress whether it is positive or negative.

3) Why?

I will try to help teachers of students with hearing problems develop the most effective way to use assistive technology in learning. This class will help the teacher and student to demonstrate my ability of using hearing aids in classroom learning.

Trimble Middle School recommends:

- Collaboration among current staff who address the academic needs of the student throughout the school 
day.

- Reduce class size to allow for providence of necessary monitoring of student's achievement in the classroom, a multisensory approach to the teaching of the student.

- Training prior to the school year to benefit the child.

\section{B. Statement and Intent}

Students with hearing impairments will need a kind of assistive technology device like a hearing aid to assist in hearing. Media can help them and language skills will be easily developed by students when using assistive technology devices.

C. Problem

- Limitations of assistive technology, like the FM amplification device and hearing aids

- Only the teacher can wear the device (difficulties when working in a group setting with peers) and privacy regarding teacher/ student or teacher/teacher communication.

D. Buy-In

The project will be extended to other levels of disabilities and we can develop other programs or systems to cover some learning disabilities. Also, it will show students' interest in learning knowledge as students without hearing impairments. Teachers will try to offer the devices that help students with any kind of disability to learn in and outside the classroom.

\section{E. Overview of the Instructional Design Project:}

- Providing research in an area that has been overlooked for years.

- Results of the research can perhaps be generalized to other areas of need.

- The approach is inclusive of learning modes/styles of learning.

- The project takes into account the fundamental learning components in teaching.

- The Ohio University student has merged his instructional education expertise with the use of technology.

\section{F. Learner Characteristics and Task Analysis}

\section{Needs Assessment}

Skills needed.

- Ability to identify the use of the hearing aids in the classroom in order to gain knowledge.

- To be able to hear properly with hearing aids.

- To have basic conversation about their names, ages and so on.

- To be able to hear and understand questions about their names, and ages.

- To be able to write some basic words after hearing them.

Knowledge needed.

- Identify the features of wearing hearing aids.

- Being able to use them.

- How to hear and understand the teacher's lesson in the classroom.

Resources.

- Assistive technology devices.

- Hearing aids.

- Access to different lessons using the Internet.

- Textbooks

Institutional support.

- More money for assistive technology to develop systems and to find other programs to help students with hearing impairments. 


\section{G. Description of Data from the Field}

The researcher plans to use video conversation between normal students and students with a hearing impairment. Normal students will realize how students with hearing impairments will understand and hear them clearly in conversation. The researcher will use records of students' conversations to assess how the interactions between the students went. Also, I will use data to assess the classroom achievement of students who use hearing aids. The researcher would ask students with a hearing impairment to determine if they already had these skills:

- Do you use hearing aids? If no, go to questions 2 and 3. If yes, go to questions 4 and 5.

- Are you familiar with using hearing aids?

- Have you heard about hearing aids before?

- Do you hear well when wearing hearing aids?

- Do you use the hearing aids in your learning or school?

*If they have no or limited hearing, then assistive technology is wanted.

\section{H. Description of Resources and Constraints}

What I have to make the course successful.

- Classroom computer access.

- Computer lab with Internet access.

- Assistive technology support specific for those with hearing impairments and other disabilities and a web site to place materials for students to access from home.

\section{Time Constraints.}

The teacher has the students for four hours every day. To access to the computer lab every day is difficult because it is shared by teachers. I need to get this unit completed within the four- week span so that I have adequate time to cover other material during the school year.

When This Instructional Unit is Complete, Teachers Will Be Able to

- Think to incorporate assistive technology and lesson preparations.

- Incorporate three specific strategies to address assistive technology in their classes and demonstrate students' abilities in their hearing skills in and outside of class.

\section{J. Instructional Objectives and Content Sequencing}

Assistive technology is defined as an item, piece of equipment or tool that provides assistance to improve functional ability in the learning environment for students with disabilities. Assistive technology is further classified as either high-tech tools that require electrical support or low-tech tools that do not require plug-in help. Examples of high-tech tools are calculators, word prediction, and voice recognition. Low-tech examples are cassette recorders, pencil grips, and head pointers.

A unique of how assistive technology makes information accessible to students with hearing impairments that may not be able to learn without assistive technology device. When discussing the translation from Thai text into Thai sign language with the Intelligent Thai text (IT), which it is for. People who are deaf or have a hearing problem can have Thai text translated into Thai sign language with the Intelligent Thai text (IT). The goal of using Thai sign language is to improve the abilities of communication and to improve access to e-educational devices to gain knowledge and learning skills for those who are deaf or have a hearing impairment. Thai people who are deaf face the problem of the difference between their sign language and second language (Thai) in syntax and semantics. In order to assist people who are deaf or who have a hearing problem, it should be a way to improve their language literacy or skills. When they have strong language skills, they will be able to access the knowledge through assistive devices like television closed captioning, teletype telephones and a speech-to-text machine translation system. However, when students who are deaf or have a hearing impairment and facing a language weakness, they may use either a human interpreter or a machine translation. Computers play an important role in language learning for all students with hearing impairments and students without them by giving them the opportunity to work on their self-based needs and increase cognitive psychology and education (Dangsaart et al., 2008).

\section{K. Goal Statement and Bloom Taxonomy}

- Identify FM system and use properly (Comprehension,Knowlege). 
- Demonstrate their abilities in the learning by using hearing aids in and outside the class (Application, Analysis, Evaluation).

- Create a conversation between two students one uses hearing aids and one does not in the classroom (Synthesis, Analysis).

- $\quad$ Use the hearing aids in the daily life and learning (Application, Synthesis).

Lesson Sequence

All the goals are taught sequentially and assessed with the whole goal. Goal reference letters may appear once for each topic because topics are not related to each other.

The goal reference letter matches the goals from the Instructional Goal listed in the previous section. See the Time Constraints section for session time (50 minutes for each lesson).

The instruction shall be face-to-face in the school. The instruction period will take over the course of approximately 10 weeks, with different objectives being taught each day (class period).

Table 1. Topics, goal reference, and number of instructional sessions

\begin{tabular}{|c|c|c|}
\hline Topic & Goal Reference & $\begin{array}{l}\text { Number of } \\
\text { instructional } \\
\text { sessions }\end{array}$ \\
\hline Hearing aids components & $\begin{array}{l}\text { Students will learn about the hearing aids } \\
\text { function. They will learn how to customize } \\
\text { them in their learning. }\end{array}$ & 1 \\
\hline $\begin{array}{l}\text { Use of assistive technology to address } \\
\text { students' need. }\end{array}$ & $\begin{array}{l}\text { Provide some example of hearing aids that } \\
\text { could be used in the classroom. }\end{array}$ & 2 \\
\hline $\begin{array}{l}\text { Cognitive model and references materials } \\
\text { and Microsoft office tools such as } \\
\text { spellcheckers, and fonts. }\end{array}$ & $\begin{array}{l}\text { Introduce some hearing devices that help } \\
\text { students with hearing impairment in the } \\
\text { classroom. }\end{array}$ & 3 \\
\hline $\begin{array}{l}\text { Electronic placement program to } \\
\text { sensitive child needs and evaluate } \\
\text { students' levels. }\end{array}$ & $\begin{array}{l}\text { Students will learn different kinds of hearing } \\
\text { devices and how to use them in and outside } \\
\text { classroom in learning and daily life }\end{array}$ & 2 \\
\hline Total Instructional Time & & 8 sessions \\
\hline Total Separate Assessment Time & & 4 sessions \\
\hline
\end{tabular}

\section{Entry Level Instruction}

\section{A. Target Audience Modified}

The target audience is students with hearing impairments. Most of them are children. The students will need to know how to listen and identify the different pieces of hearing aids that fit with each individual need. They will also need to have some experience with different sounds. Presently, the class is being taught the basic information of how to use hearing aids in the classroom. The teacher will continue throughout the fall to review and teach a lesson by using hearing aids. The teacher should have students wear hearing aids properly. Students must be able to wear and identify the hearing aid device.

\section{B. Task Analysis}

Students will hear and identify the classroom lessons through the devices for hearing impairments.

This objective and the lesson combine the objectives from previous lessons. I believe that a teacher could teach this by showing how it relates to the previous learning sessions. The teacher could have students identify the difference between words. The teacher will teach students with hearing problems how to promote the devices to understand the word. Also, I would look at specific hearing devices for learning models to use it for teaching and learning setting. 


\section{Instructional Objectives and Strategies}

The Learning Goals of the Curriculum

- Students should be able to demonstrate their ability through using hearing aids in the classroom.

- Students should demonstrate their ability to say very basic words.

- Students should be able to apply the knowledge their hearing.

- Students should be able to listen and speak some words during conversation in the class through observation or instrument use by teacher evaluation.

The definition of assistive technology is an item or piece of equipment that helps the operational level of the learning atmosphere for students with disabilities. Also, being further classified, assistive technology is high tech items that need electrical assistance or they can also be low tech tools that do not require that help. Some of these high tech items are voice recognition, calculators, and word predictors. Some low tech items are cassette recorders, pencil grips, and head pointers. To further assist students, FM devices can be used in the classroom to help them. To better spread the teacher's voice, he or she can wear an FM transmitter. This can also attend to students needs so that their classrooms are better prepared for them. An example of this is the usage of a microphone by a teacher that delivers his or her voice to the students' hearing aids or cochlear implants.

See Appendix A (teachers' reaction to students wearing hearing aids).

D. The Assessments That Teacher Needs for the Curriculum

Table 2. Tools, rational, assessment, and measurement tools (Formal)

\begin{tabular}{|c|c|c|c|}
\hline Tool & Rationale & $\begin{array}{c}\text { When \& } \\
\text { Formative/Summative }\end{array}$ & Measurement Tools \\
\hline $\begin{array}{l}\text { Needs assessment } \\
\text { (performance } \\
\text { assessment) }\end{array}$ & $\begin{array}{l}\text { To decide the students' } \\
\text { prior knowledge in } \\
\text { wearing hearing aids. } \\
\text { Teacher's knowledge of } \\
\text { assistive technology } \\
\text { such as hearing aids }\end{array}$ & Prior to class & $\begin{array}{c}\text { Criterion-referenced } \\
\text { performance measures } \\
\text { (performance on hearing skills) }\end{array}$ \\
\hline $\begin{array}{c}\text { Student } \\
\text { self-assessment } \\
\text { (reflection logs) }\end{array}$ & $\begin{array}{l}\text { Giving students a } \\
\text { survey to ask the pros } \\
\text { and cons of using } \\
\text { hearing aids. }\end{array}$ & $\begin{array}{l}\text { Formative } \\
\text { A reflection log per day } \\
\text { by daily journal. }\end{array}$ & $\begin{array}{l}\text { Criterion-referenced } \\
\text { performance measures }\end{array}$ \\
\hline
\end{tabular}

Table 3. Tools, rational, assessment, and measurement tools (Informal)

\begin{tabular}{|c|c|c|c|}
\hline Tool & Rationale & $\begin{array}{c}\text { When \& } \\
\text { Formative/Summative }\end{array}$ & Measurement Tools \\
\hline $\begin{array}{l}\text { Participation } \\
\text { (checklist) }\end{array}$ & $\begin{array}{l}\text { Someone watches students and } \\
\text { how interact by using hearing } \\
\text { aids. }\end{array}$ & $\begin{array}{l}\text { Formative } \\
\text { ongoing throughout class }\end{array}$ & $\begin{array}{l}\text { Observation with formal } \\
\text { checklist of participation }\end{array}$ \\
\hline $\begin{array}{l}\text { End-of-Class } \\
\text { Evaluation } \\
\text { (curriculum } \\
\text { Survey) }\end{array}$ & $\begin{array}{l}\text { Gain students input and answer } \\
\text { to improve the curriculum } \\
\text { Survey and add toward both } \mathrm{t} \\
\text { and s }\end{array}$ & $\begin{array}{l}\text { Summative } \\
\text { End of curriculum } \\
\text { Summative }\end{array}$ & Survey \\
\hline
\end{tabular}

\section{E. Still Need}

Make sure that the materials are cleared coherent and well design and organized. Also, it should have a contact specialist (students with hearing impaired) in the classroom beside the teacher. It should be some movies established in Athens, Ohio to give students a chance to hear and watch. Also, students should be identified what 
they heard.

Development of Instruction, Instructional Strategies and Designing the Message.

Distinguishing English Consonants and Vowels From One Syllable to Multiple Syllables goals addressed.

- Students will evaluate the use of hearing aids and the quality of sounds.

(Recall-Comprehension)

- $\quad$ Students will identify each letter and words they hear. (Recall)

Time allocation (One 45 minute class period)

Table 4. Activities, time, presentation methods, ID theory, and the role of teachers and students

\begin{tabular}{|c|c|c|c|c|}
\hline Activity & $\begin{array}{l}\text { Time in } \\
\text { (minutes) }\end{array}$ & $\begin{array}{l}\text { Presentation } \\
\text { Method/Student } \\
\text { Grouping }\end{array}$ & ID Theory & $\begin{array}{l}\text { What students and teachers } \\
\text { do! }\end{array}$ \\
\hline $\begin{array}{l}\text { Opening-review the } \\
\text { association with } \\
\text { English sound. }\end{array}$ & 10 & Large group & $\begin{array}{l}\text { Focus } \\
\text { attention/motivation? }\end{array}$ & $\begin{array}{l}\text { Teacher helps and assists } \\
\text { students in groups. } \\
\text { Students complete review } \\
\text { drills designed to identify } \\
\text { previous knowledge of } \\
\text { English sound (phonics). }\end{array}$ \\
\hline \multirow{2}{*}{ Note taking } & \multirow{2}{*}{15} & \multirow{2}{*}{ Large group } & \multirow{2}{*}{ Process information } & $\begin{array}{l}\text { Students copy examples } \\
\text { and information presented } \\
\text { by teacher in verbal and } \\
\text { written form with the } \\
\text { association of FM system. }\end{array}$ \\
\hline & & & & $\begin{array}{lr}\text { Teacher } & \text { presents } \\
\text { information and } & \text { questions } \\
\text { students to } & \text { make } \\
\text { distinctions } & \text { between } \\
\text { different English words. }\end{array}$ \\
\hline & & & & $\begin{array}{l}\text { Students will work through } \\
\text { examples with direction } \\
\text { from teacher. }\end{array}$ \\
\hline Guided Practice & 10 & Large group & $\begin{array}{l}\text { Practice } \\
\text { feedback }\end{array}$ & $\begin{array}{l}\text { Teacher will guide student } \\
\text { by providing example, } \\
\text { giving needed help with } \\
\text { each example, and asking } \\
\text { students about the process. }\end{array}$ \\
\hline Individual Practice & 8 & Individual & Practice & $\begin{array}{l}\text { Students practice on their } \\
\text { own with only limited } \\
\text { teacher assistance. }\end{array}$ \\
\hline Closing & 2 & Large group & Closure & $\begin{array}{l}\text { Teacher will go over the } \\
\text { topic and provide advance } \\
\text { notice of next day's topic. } \\
\text { Also, teacher assigns } \\
\text { homework. }\end{array}$ \\
\hline
\end{tabular}

The Function of English Sound goals addressed.

- Students will evaluate the use of the FM system with association of English sound. (Recall-Comprehension)

- Evaluate the students understanding using FM system (Comprehension). 
Table 5. Activities, time, presentation methods, ID theory, and the role of teachers and students

\begin{tabular}{|c|c|c|c|c|}
\hline Activity & $\begin{array}{l}\text { Time in } \\
\text { (minutes) }\end{array}$ & $\begin{array}{l}\text { Presentation } \\
\text { Method/Student } \\
\text { Grouping }\end{array}$ & ID Theory & $\begin{array}{l}\text { What students and teachers } \\
\text { do! }\end{array}$ \\
\hline \multirow{3}{*}{$\begin{array}{l}\text { Opening-review } \\
\text { previous lesson } \\
\text { material }\end{array}$} & \multirow{3}{*}{10} & \multirow{3}{*}{ Large group } & \multirow{3}{*}{$\begin{array}{l}\text { Focus } \\
\text { attention/motivation? }\end{array}$} & $\begin{array}{l}\text { Teacher watches and } \\
\text { assists students in group. }\end{array}$ \\
\hline & & & & $\begin{array}{l}\text { Students use FM system to } \\
\text { hear teacher's speech. }\end{array}$ \\
\hline & & & & $\begin{array}{l}\text { Teacher reviews the } \\
\text { material with large group. }\end{array}$ \\
\hline \multirow{2}{*}{ Guided Practice } & \multirow{2}{*}{14} & \multirow{2}{*}{ Large group } & \multirow{2}{*}{ Practice with feedback } & $\begin{array}{l}\text { Students will apply FM } \\
\text { system in lesson learning } \\
\text { through examples with } \\
\text { help from teacher. }\end{array}$ \\
\hline & & & & $\begin{array}{l}\text { Teacher will guide student } \\
\text { through example word } \\
\text { recognition, giving less } \\
\text { help with each example. }\end{array}$ \\
\hline Guided practice & 10 & Large group & $\begin{array}{l}\text { Practice/motivation. } \\
\text { (Students like making up } \\
\text { words) }\end{array}$ & $\begin{array}{l}\text { Students will be called } \\
\text { upon by the teacher to } \\
\text { complete examples on the } \\
\text { board. The students } \\
\text { completing the tasks will } \\
\text { be encouraged to ask } \\
\text { classmates for assistance. }\end{array}$ \\
\hline $\begin{array}{l}\text { Introduction to } \\
\text { 2nd day material }\end{array}$ & 10 & Large group & $\begin{array}{l}\text { Attention and motivation. } \\
\text { (Students will ask to make } \\
\text { up other words for the next } \\
\text { day. }\end{array}$ & $\begin{array}{l}\text { Teacher will begin to give } \\
\text { basic instruction about } \\
\text { how to be familiar with } \\
\text { FM system. The students } \\
\text { will listen to the radio and } \\
\text { teacher's speech. }\end{array}$ \\
\hline Closing (Day \#1) & 1 & Large group & Closure & $\begin{array}{l}\text { Teacher will assign } \\
\text { homework to be completed } \\
\text { for the next day. }\end{array}$ \\
\hline
\end{tabular}

Practice and Practice and Practice goals addressed.

- Given two points (ordered pairs), students will be able to relate the letter to the sound or the word with the sound (Comprehension).

- Given a list of words, students will be able to determine letters in each word they hear (Comprehension). 
Table 6. Activities, time, presentation methods, ID theory, and the role of teachers and students

\begin{tabular}{|c|c|c|c|c|}
\hline Activity & $\begin{array}{l}\text { Time in } \\
\text { (minutes) }\end{array}$ & $\begin{array}{l}\text { Presentation } \\
\text { Method/Student } \\
\text { Grouping }\end{array}$ & ID Theory & What students and teachers do! \\
\hline \multirow{2}{*}{ Opening } & \multirow{2}{*}{15} & \multirow{2}{*}{ Large group } & \multirow{2}{*}{$\begin{array}{l}\text { Focus } \\
\text { attention }\end{array}$} & $\begin{array}{l}\text { Teacher observe and assists } \\
\text { individual students }\end{array}$ \\
\hline & & & & $\begin{array}{l}\text { Teacher reviews the material with } \\
\text { large group. }\end{array}$ \\
\hline \multirow{2}{*}{$\begin{array}{l}\text { Note taking/guided } \\
\text { practice }\end{array}$} & \multirow[b]{2}{*}{19} & \multirow[b]{2}{*}{ Large group } & \multirow{2}{*}{$\begin{array}{l}\text { Process } \\
\text { information }\end{array}$} & $\begin{array}{l}\text { Students copy examples and } \\
\text { information presented by teacher } \\
\text { in verbal and written form. }\end{array}$ \\
\hline & & & & $\begin{array}{l}\text { Teacher presents information and } \\
\text { questions students to make } \\
\text { distinctions between different } \\
\text { examples }\end{array}$ \\
\hline Individual Practice & 10 & Individual & Practice & $\begin{array}{l}\text { Students practice on their own } \\
\text { with only limited teacher } \\
\text { assistance. }\end{array}$ \\
\hline Closing (Day \#1) & 1 & Large group & Closure & Teacher will recap the topic \\
\hline Opening & 20 & Individual/Large & $\begin{array}{l}\text { Formative } \\
\text { Assessment }\end{array}$ & $\begin{array}{l}\text { Teacher observe and assists } \\
\text { individual students }\end{array}$ \\
\hline (Day \#2) & & group & $\begin{array}{l}\text { Review } \\
\text { material }\end{array}$ & $\begin{array}{l}\text { Teacher reviews the material with } \\
\text { class. }\end{array}$ \\
\hline Practice & 10 & Individual & Practice & \\
\hline $\begin{array}{l}\text { Closure/Preview } \\
\text { (Day \#2) }\end{array}$ & 15 & Large Group & $\begin{array}{l}\text { Preview } \\
\text { next day }\end{array}$ & $\begin{array}{l}\text { Teacher sums up the rules of } \\
\text { forming word and the places for } \\
\text { sounds articulation. }\end{array}$ \\
\hline
\end{tabular}

Development of Instruction.

Letter/Word Recognition goals addressed.

- Given a hearing representations such as television; students will identify the sounds through wearing hearing aids.

- $\quad$ Students will learn the use of hearing aids in learning environment.

- $\quad$ K. Students will identify sounds in each word.

- G. Students will identify the letters of each word (Comprehension).

Teacher will dictate to students some English words to test their hearing while wearing hearing aids. In addition, the discussion helps students to find out advantages and disadvantages of using hearing aids in the classroom and develop their hearing skills and oral communication. The main objective of this lesson is for students to determine the words they hear. The teacher says the words or uses a recorder and the student will write what they hear. The teacher and students repeat some words. As for drilling, the teacher will dictate some words and students write them on their note book. Then, the teacher writes these words on the board and the students correct their mistakes. In the last stage, the teacher gives students a sheet and asks them to circle the word they hear. The list of the words includes words that have letters that may sound close to students. At the end, the teacher says the words in the list and explains how the two sounds are different.

The purpose of lesson is to develop students' hearing of teacher's speech. Therefore, instructors would like to divide students to several small groups to cooperate to determine the words they heard from the teacher.

Hearing aids in the classroom are not only used to hear teachers. They could be used in other purposes, such as listening to movie or television. The media that I will first use in this section are the computer, television, radio, 
and audacity. The computer is one of the many options that are at teachers' disposal. An example of computer usage is when a teacher uses animal pictures for the students to hear their names, and then chooses the name of the animal, that goes with the picture. One possibility could be that lab may have several teachers wanting to use the lab at the same time. Television will be the primary media that teachers use in the classroom, followed by radio, which is another media device for students with hearing impairment to use in and outside classroom. Audacity allows teachers to record the voice of the word and the students can listen to the recording. I think the usage of previous devices is easy as a method of instruction. They can be used in the classroom for assisting students with hearing problems. Also, they will help students to learn and hear as their peers. Students will enrich their information and thus show new skills that they will be exposed to in that day's lesson, via teacher lecture, and class discussion. Next, they will actively participate in the educational process by practicing the skills that they have been working on. Most days, the students will make a tangible hardcopy of the homework assignment for the teacher to perform an evaluation. The students in this class will be using the programs a lot. They should be acquainted with the task at hand. After this, the instructor will be able to make a model and students will be able to practice. The teacher can pronounce each word easier than using video tape and so on. Therefore, technology tools or media have advantages and disadvantages in teaching language. The basic instruction will be through the teacher. The textbook should be a mode of instruction, not the only instruction. Also, the ability to adapt a way of instruction or explain examples different will be important. Hopefully, by the last couple of years media will be used and communication is essential.

In addition to the medial discussed above.

Table 7. The advantages and disadvantages of media

\begin{tabular}{lll}
\hline Media & Advantage & Disadvantage \\
\hline Television & Models help students to hear speech. & $\begin{array}{l}\text { Students might depend on TV and stay } \\
\text { away from the teacher and textbook. } \\
\text { Audacity }\end{array}$ \\
$\begin{array}{l}\text { Audacity allows teachers to record their voice of the } \\
\text { word and the students can listen to the recording } \\
\text { Radio }\end{array}$ & $\begin{array}{l}\text { Radio can be used in the classroom for assisting } \\
\text { students }\end{array}$ & $\begin{array}{l}\text { Oasier than the video tape } \\
\text { they think it is outdoor medial. }\end{array}$ \\
i pods & It will help students to keep hearing lots sounds. & $\begin{array}{l}\text { Students might not be familiar with how to } \\
\text { use an I pod in the classroom }\end{array}$ \\
\hline
\end{tabular}

\section{Evaluation}

According to Reiser and Dempsey (2007) evaluation is the process of determining to what extent the educational objectives are met. In other words, it is the process for determining the degree in which changes in behavior are actually taking place. There are two parts in the concept of evaluation: it must appraise students' behavior and it should involve at least three stages of appraisal. The first should be in the early part of the program, the second at a later point, so the changes may be measured, and the third after the program has been completed. Evaluation has a powerful influence upon learning and provides information about the success of school to the public. It can be accomplished through several methods (test, observation, interview, questionnaire, students' products, and school records). Evaluation findings are useful to suggest hypotheses, and then check these hypotheses against the present data; if they appear to be consistent with the available data. The next step is to modify the curriculum and then teach the materials to see the improvement in students' achievement. Kirkpatrick's evaluation procedures are parallel to the educational objectives of the curriculum. Kirkpatrick discussed four-level models of training evaluation: reaction, learning, behavior, and results, among which I argue that learning evaluation is the most effective component in Kirkpatrick's model. As this instructional design is based on the innovation in using assistive technology, the evaluation will be an on-going process from the rapid prototyping. The summative evaluation will start from the progress of using assistive technology for the effectiveness and the evaluation will be done after testing students. Teacher will evaluate students through testing them and the scores will show if there is progress. 
Table 8. Design product, method, rational, and participants

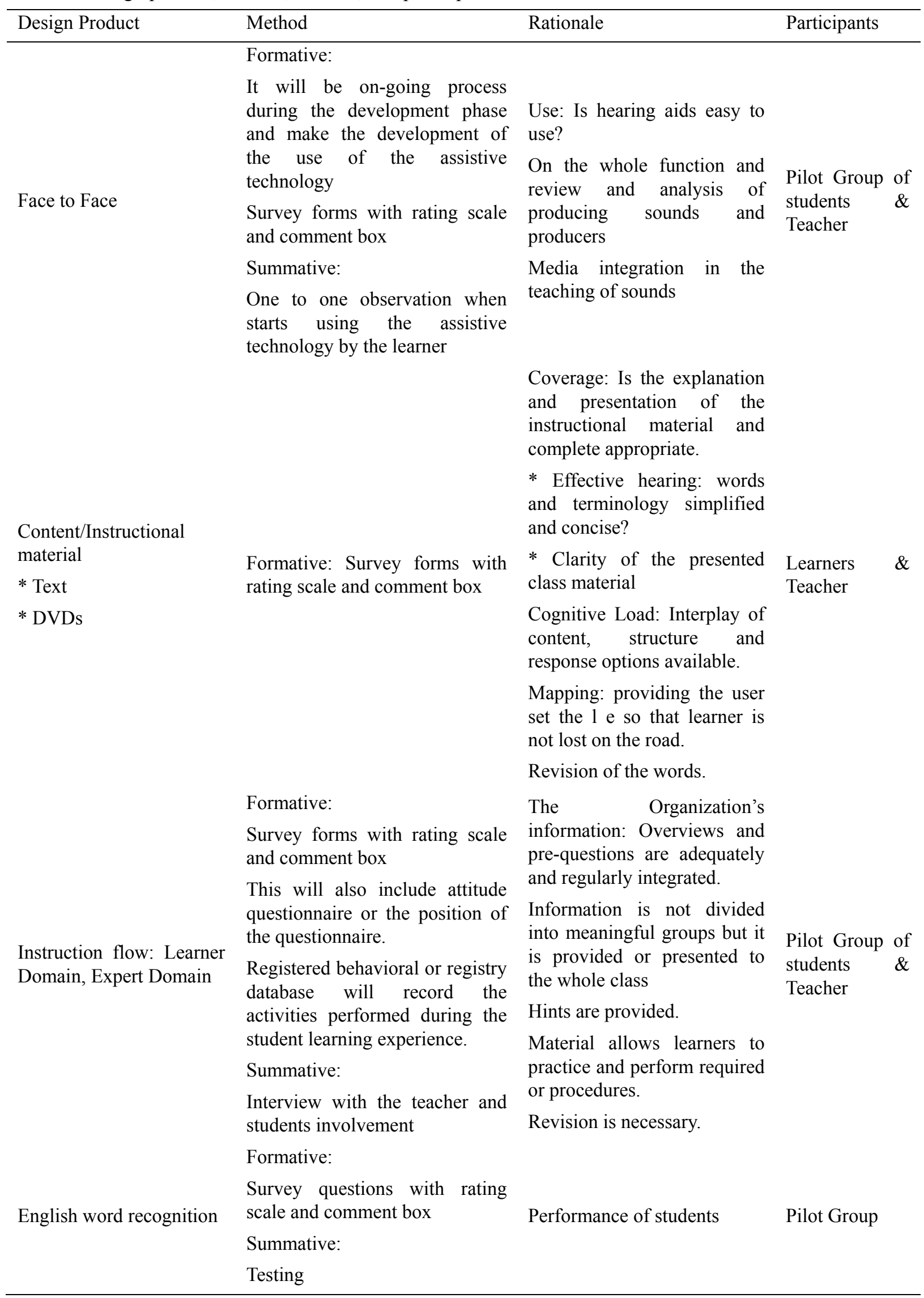


Implementation Plan (destination of all process above).

A lot of students with hearing problems still learn in and outside of school. There is an increasing need in the school of having teachers know how to implement hearing aids in instructions. Also, there is lot of research initiatives involving hearing aids in the classroom for students as it is going to be a collaborative project, and there is a need for the development of this tool. The adoption will depend on the results of testing and the stockholder's demand. Kemp instructional design provides for a systematic approach to customize the instruction in the education plan

Instructional design models.

According to Morrison et al. (2007) Kemp's design model applies a comprehensive approach to instructional design. The Kemp's design model is an instrument design method that lists nine different parts and also adapts a continuous evaluation model. Kemp's design model is a continuous cycle that it is design to bring about good instruction. It accounts for several variables within the learning environment, such as the analysis of the topic, characteristics of the learners, learning objectives, teaching activities, resources, support services and evaluation. This design model focuses mainly on the needs of the learner and a self-reflective review of content. More specifically it can also be useful for an individual's lesson. During our time when technology so greatly influences the lives of people, the Kemp model along with technology can be beneficial for the arena of education. The benefits of the Kemp model over the ADDIE and the four- component instructional design model are many. They include a greater focus on the cognition of students and a greater sensitivity to learning styles which includes the auditory, visual and multi-sensory approach. The Kemp program also adds structure through a diagram. It often references heavily past research. The background for this type of study is rich and the authors of this model are well educated. They list steps plainly, making it easy to follow. In this simple model, the ideas are circular not linear and it is possible to do many things with more breadth at the same time. It is easy to convey to teachers in less time, applicable, and easy to understand.

The Kemp model is more thorough than the four-component instructional design model. According to Reiser and Dempsey (2007) the four component instructional model has only four main parts, the learning tasks, supportive information, part-task practice and procedural information. The four component instructional design model is a long term instructional design model that often takes months or years and often leads to the development of long term learning and training program. The model does not give sufficient examples of how this four component instructional design was used before. It is older and less research- based and therefore it will be hard to get teacher acceptance and usage. The four component model is less user-friendly because it requires essential knowledge of cognitive or child development and is more time intensive, requiring more teacher training, and more professional abilities. The Kemp model is better able to take on a breadth of topics and is more accessible for the average teacher.

According to Reiser and Dempsey (2007) in contrast with four component instructional design model ADDIE instructional design model has five steps traditional process used by instructional designers and training developers. The ADDIE model is more of a generic process and not as thorough as a Kemp model: analysis, design, development, implement, and evaluation. It should be used only after understanding Kemp's design model. There have not been ample studies shown whether this particular instructional design model is useful or not. ADDIE does not give sufficient example and whether design was used before. It is less research based on and new. The Kemp model is superior and ADDIE should be used as a secondary, not primary source.

\section{Conclusion}

Based on Kemp's model the researcher found FM systems and hearing aids devices enhances and enables students with hearing impairments. These devices used with a sound learning model, the system maximize students learning by giving students with hearing problem opportunities access information in learning environments. The Kemp model the most suitable for this class design. Teachers may find Kemp's model is an easy way of instruction and well organized and applicable in the classroom. For example, according to Morrison et al. (2007) say when teachers aware of basic principles of how to design instruction, that can assist to implement a necessary purpose, meet the needs of students, is attractive and well organized. The model is structured and relates well to individual difference. Kemp's model can be adapted across cultures in various educational settings. It gives an accessible basis to develop a positive transfer of learning. The Kemp's model that includes the nine important types that help students to be problem solvers, think to solve problems, help students to use their motor skills, improve students' personality creativity, and reflect their beliefs. The Kemp's model is beneficial for students and teachers in the twenty-first century because it is more comprehensive than other ADDIE and four component instructional design model. The model allows individualized student thinking. 
Students can be creative in the education. Kemp's model recognizes talented or gifted students, as observed by the teacher.

\section{References}

Dangsaart, S., Naruedomkul. K., Cercone, N., \& Sirinaovakul, B. (2008). Intelligent thai text-thai sign translation for language learning. Computer \& Education, 51(3), 1125-1141. http://dx.doi.org/10.1016/j.compedu.2007.11.008

Morrison, G. R., Ross, S. M., \& Kemp, J. E., \& Kalman, H. K. (2007). Designing effective instruction. Hoboken, NJ: John Wiley \& Sons.

Reiser, R. A., \& Dempsey, J. V. (2007). Trends and Issues in Instructional Design and Technology. Upper Saddle River, NJ: Person Education.

\section{Appendix}

This questionnaire consists of five questions, which have to be related by the respondents on a five point rating scale:

5-Strongly agree.

4-Agree.

3-Neutral.

2-Disagree.

1-Strongly disagree.

Instruction

This questionnaire contains questions which have to be rated on 5-1 rating:

As an educator, I feel comfortable when students using hearing aids in the classroom.

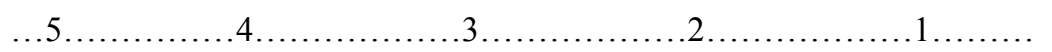

I believe students will comprehend the lesson easier when wearing hearing aids.

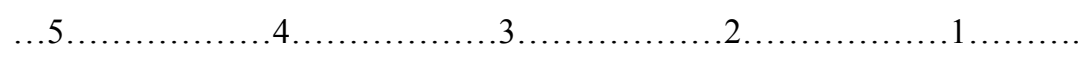

I like to use FM systems for students with hearing impairment in classroom due to noise factor.

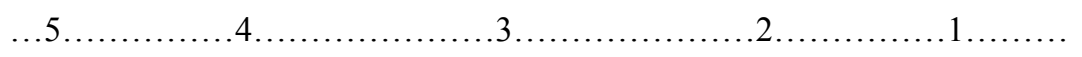

Students will be able to hear conversation and learn spoken language with relative ease, particularly for those with severe-profound hearing loss.

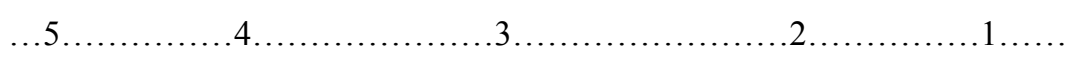

Hearing aids have increased the access of general curriculum for students with hearing impairment.

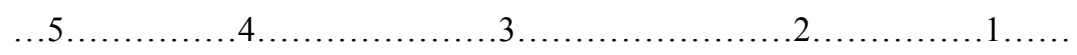

\section{Copyrights}

Copyright for this article is retained by the author(s), with first publication rights granted to the journal.

This is an open-access article distributed under the terms and conditions of the Creative Commons Attribution license (http://creativecommons.org/licenses/by/3.0/). 